\title{
KOMUNIKASI MATEMATIS SISWA TUNARUNGU MELALUI MODEL PEMBELAJARAN THINK PAIR SHARE
}

\author{
Ari Suningsih" ${ }^{1)}$, Yunni Arnidha ${ }^{2)}$ \\ ${ }^{1,2}$ STKIP Muhammadiyah Pringsewu, Lampung \\ Email: ari.suningsih@ stkipmpringsewu-lpg.ac.id ${ }^{1)}$ \\ yunniarnidha@stkipmpringsewu-lpg.ac.id ${ }^{2)}$
}

\begin{abstract}
Communication ability in this study focused on the mathematical communication of oral and written to the tunarungu students in SLB N Pringsewu. The research topic is directed to the original condition in which the research subject is located. The data collection was done by using the test method and observation of learning process with the aid of Handycam. The data that will be obtained in this research is data about how the process of mathematical communication of students in learning mathematics after applying the learning model of Think Pair Share. In the mathematical communication in writing, the tunarungu students are able to use mathematical symbols or mathematical symbols correctly but are unable to write down the problem situation in the form of mathematical formulas or models and can not state the results of the answers in a row and correctly. Mathematical oral communication of students can be able to express symbols or mathematical symbols correctly and unable to use mathematical formulas or models in conveying explanations.
\end{abstract}

Keywords: mathematics communication, think pair share, tunarungu students

\section{PENDAHULUAN}

Matematika merupakan ilmu universal yang mendasari perkembangan teknologi modern serta mempunyai peranan penting dalam memajukan daya pikir manusia. Oleh karena itu matematika diberikan pada peserta didik mulai dari jenjang pendidikan dasar sampai perguruan tinggi. Tanpa terkecuali, peserta didik berkebutuhan khususpun berhak mendapatkan pengetahuan matematika. Sebagaimana komitmen pemerintah yang tertuang dalam Undang-Undang RI No 20 Tahun 2003 tentang Sistem Pendidikan Nasional pada pasal 5 ayat 2, dijelaskan bahwa warga negara yang memiliki kelainan fisik, mental, emosional, intelektual dan sosial berhak mendapatkan pendidikan khusus.

Sekolah luar biasa (SLB-B) bagian B merupakan salah satu wadah formal, sebagai wujud nyata yang diberikan pemerintah untuk memberikan pelayanan pendidikan bagi siswa tunarungu. Anak tunarungu memiliki keterbatasan dalam hal mendengar dikarenakan tidak berfungsinya organ-organ pendengaran, mereka tidak mampu memahami bentuk komunikasi audio dari lingkungan sekitarnya. Terhambatnya indra pendengaran, mengakibatkan siswa tunarungu tidak mampu memahami bahasa dengan baik, sehingga mereka mendapatkan beberapa perlakuan yang berbeda dengan siswa normal dalam pembelajaran. Fasilitas belajar khusus yang disesuaikan dengan kondisi fisik siswa tunarungu, diantaranya jumlah maksimum rombongan belajar hanya 8 siswa, sedangkan rombongan belajar 
pada siswa normal dapat mencapai 40 siswa dalam setiap kelasnya. Selain itu dapat pula dilakukan dengan pengaturan kurikulum dan jadwal yang bersifat fleksibel.

Pembelajaran merupakan salah satu kegiatan utama dalam meningkatkan kecerdasan siswa, baik dalam sekolah reguler ataupun sekolah luar biasa (SLB). Guru mengemas proses pembelajaran dengan menggunakan bahasa tubuh sebagai alat komunikasi untuk menyampaikan konsep yang dipelajari. Mata pelajaran yang harus dipelajari siswa, baik siswa regular maupun siswa berkebutuhan khusus di setiap jenjang pendidikan adalah mata pelajaran matematika. Dengan mempelajari matematika, siswa akan terlatih kemampuannya dalam berpikir logis, kritis, analitis, kreatif dan aditif terhadap perubahan dan perkembangan jaman. Mundia (2010: 150) bahwa matematika mempunyai hubungan yang erat dan banyak digunakan dalam berbagai situasi serta masalah dalam kehidupan sehari-hari. Kemampuan tersebut memiliki peranan yang sangat strategis dalam menyiapkan sumberdaya manusia berpotensi. Selanjutnya kemampuan berpikir logis, kritis, analitis, kreatif dan aditif dapat dikembangkan melalui kemampuan siswa dalam mengkomunikasikan ide matematika. Melalui komunikasi matematis siswa dapat mengorganisasikan dan mengkonsolidasi berpikir matematisnya sehingga dapat memberikan respon yang positif antar siswa dan media dalam proses pembelajaran. Alasan penting lainnya mengapa komunikasi dalam pembelajaran matematika perlu ditumbuhkembangkan di kalangan siswa, karena matematika tidak hanya sekedar alat bantu berpikir untuk menemukan pola dalam menyelesaikan masalah atau mengambil kesimpulan tetapi matematika merupakan cara mengkomunikasikan gagasan secara praktis, sistematis dan efisien. Hal inilah yang menjadikan pemerintah melalui Peraturan Menteri Pendidikan Nasional tahun 2006 menetapkan kemampuan komunikasi menjadi salah satu standar kompetensi lulusan bagi siswa sekolah dasar sampai menengah dalam pembelajaran matematika.

Merujuk pada permendiknas tersebut, diharapkan guru dapat membangun dan mengembangkan komunikasi matematis baik secara lisan maupun tulisan dalam kegiatan pembelajaran pada setiap jenjang pendidikan regular maupun pendidikan berkebutuhan khusus. Akan tetapi kondisi real di SMPLB-B, berdasarkan hasil penelitian Sutriningsih (2015) ditemukan rendahnya kemampuan siswa tunarungu dalam mengkomunikasikan konsep matematika secara lisan. Mereka hanya mampu mengungkapkan lambang (symbol) matematika dengan benar, namun mereka belum mampu menyajikan dan menjelaskan penyelesaian masalah serta menjelaskan kesimpulan yang diperoleh. Kurangnya kemampuan komunikasi lisan mereka disebabkan oleh kurangnya guru memberikan tugas dalam berbagai variasi dan kurangnya keterlibatan mereka dalam kegiatan diskusi. Hal ini terlihat dari hasil pengamatan, selama berlangsungnya proses pembelajaran guru tidak menggunakan metode diskusi dan tugas. Guru lebih dominan menggunakan metode ceramah dan pemberian tugas yang kurang bervariasi. Tugas yang diberikan pada siswa sebagai latihan memiliki pola yang sama dengan permasalahan yang diberikan sebagai contoh hanya dengan sedikit mengubah bilangannya (besarannya). Kurangnya pemahaman siswa pada umumnya dan khususnya siswa tuna rungu yang memiliki 
keterbatasan pada indra pendengaran terhadap konsep matematika, ternyata pembelajaran matematika yang selama ini hanya dijadikan tempat mengaplikasikan konsep. Akibatnya matematika dirasa sebagai ilmu yang sulit dan tidak menarik.

Pemahaman matematika secara konseptual dapat dibangun melalui pemecahan masalah, penalaran dan argumentasi. Pemaknaan argumentasi dalam hal ini tentunya melibatkan kemampuan berkomunikasi baik secara lisan maupun tulisan, jadi dengan mendorong siswa untuk dapat menjelaskan dengan berbagai cara, seorang guru tidak hanya memvalidasi siswa secara individual akan tetapi membangun pemahaman matematika siswa. Hal ini didasari oleh hasil penelitian LACOE (2004) mempertegas melalui hasil penelitiannya bahwa diskusi kelompok merupakan cara yang dipandang tepat untuk mengembangkan kemampuan komunikasi matematis lisan siswa. Sedangkan Munandar (2014) bahwa guru dapat mempercepat peningkatan komunikasi matematika siswa melalui penerapan model pembelajaran kooperatif tipe TPS. Sedangakn Husna (2013) mengatakan peningkatan kemampuan komunikasi matematis siswa sekolah menengah pertama yang memperoleh model pembelajaran tipe Think Pair Share lebih baik daripada siswa yang memperoleh pembelajaran konvensional. Sedangkan hasil penelitian Suningsih, Kusmayadi, dan Riyadi (2014) menyatakan bahwa model pembelajaran kooperatif tipe TPS mampu meningkatkan prestasi siswa yang rendah.

Uraian tersebut memberikan makna bahwa kemampuan siswa tunarungu dalam meguasai konsep matematika dapat dibangun melalui pengembangan komunikasi matematisnya secara lisan dan tulisan, melalui metode diskusi dan pemberian tugas variatif. Metode diskusi dan pemberian tugas variatif dapat didesain melalui model pembelajaran inovatif progresif, salah satunya adalah model pembelajaran Think Pair Share (TPS). Arends (1997) disadur menyatakan bahwa think- pair- share merupakan cara yang efektif untuk membuat variasi suasana pola diskusi kelas. Melalui fase think, siswa dituntut untuk berpikir tentang jawaban dari permasalahan dan yang diberikan guru. Selanjutnya pada fase pair, siswa berpasangan untuk mendiskusikan dan menyatukan jawaban. Pada fase akhir share siswa diminta untuk mengkomunikasikan jawaban atau gagasannya kepada pasangan yang lain secara keseluruhan.

Dengan demikian penelitian ini dilaksanakan sebagai tindak lanjut penelitian sebelumnya sebagai upaya meningkatkan pemahaman konsep matematika siswa melalui peningkatan kemampuan komunikasi matematisnya yang dibangun dan dikembangkan dengan menerapkan model pembelajaran TPS. Oleh karena itu penelitian ini bertujuan untuk mengetahui kemampuan komunikasi matematika siswa tunarungu secara lisan dan tulisan melalui model pembelajaran TPS

\section{METODE PENELITIAN}

Penelitian ini digolongkan ke dalam penelitian deskriptif berjenis studi kasus. Hal ini sesuai dengan yang dikemukakan oleh Asmani (2011: 43), bahwa pada dasarnya studi kasus digunakan untuk mempelajari secara mendalam bagaimana individu atau kelompok melakukan sesuatu. Dalam penelitian ini, studi kasus yang dimaksud adalah mempelajari secara mendalam bagaimana komunikasi matematis siswa tunarungu secara tertulis dan lisan 
setelah menerapkan model pembelajaran TPS.

Indikator Kemampuan komunikasi matematis tertulis pada penelitian ini antara lain 1) siswa dapat menuliskan gagasan (yang diketahui dan ditanya) serta dapat menggambarkan situasi masalah dalam bentuk rumus ataupun model matematika. 2) siswa dapat menyatakan hasil jawaban secara runtun dan benar, 3) siswa dapat menggunakan simbol atau lambang matematika secara tepat. Sedangkan kemampuan komunikasi matematis lisan sebagai berikut: 1) siswa dapat menggunakan rumus ataupun model matematika dalam menyampaikan penjelasan, 2) siswa mampu mengungkapkan lambang atau simbol matematika dengan benar.

Penelitian ini menggunakan bantuan alat perekam berupa handycame untuk mengamati interaksi guru dan siswa tunarungu dalam pembelajaran matematika yang sedang berlangsung di kelas VII SMPLB Negeri Pringsewu, namun tidak ikut serta atau terlibat langsung dalam kegiatan pembelajaran. Hal ini sesuai dengan pendapat Stainback (dalam Sugiyono, 2011: 312) bahwa dalam observasi partisipasi pasif peneliti hanya datang ditempat kegiatan orang yang akan diamati, tetapi tidak ikut terlibat dalam kegiatan tersebut.

Instrumen dalam penelitian ini adalah soal tes, wawancara, observasi. Data diambil melalui interaksi guru dan siswa tunarungu dalam kegiatan pembelajaran matematika dengan menggunakan instrumen tes hasil belajar dan alat bantu berupa handycame.

Data yang diperoleh dengan instrumen tes dan alat bantu handycame berupa rekaman kegiatan pembelajaran dikelas. Selanjutnya dianalisis berdasarkan indiktor matematis tulis pada siswa tunarunggu. Untuk mengetahui komunikasi matematis tulis siswa hasil pekerjaan siswa pada LKS, aktivitas siswa selama proses pembelajaran di kelas sehingga diperoleh data komunikasi matematis tulisan berdasarkan indikator.

\section{HASIL PENELITIAN DAN PEMBAHASAN}

Pada penelitian ini subyek yang diamati diberi model pembelajaran Think Pair Share. Pada awal kegiatan Menyampaikan tujuan pembelajaran dan memotivasi siswa dalam langkah ini guru menyampaikan tujuan pembelajaran yang akan dicapai melalui model pembelajaran kooperatif tipe TPS. Langkah apersepsi dilakukan melalui tanya jawab. Guru mengecek kemampuan siswa tentang materi sebelumnya dalam hal ini materi tentang bilangan bulat.

Pada kegiatan inti: Guru mempresentasikan secara garis besar tentang materi yang akan didiskusikan, Guru memberikan LKS pada peserta didik tentang materi yang akan didiskusikan dengan memberikan materi yang relevan dan dikerjakan secara individu (think), peserta didik membentuk kelompok sesuai dengan teman duduk dalam satu bangku dengan membawa hasil penyelesaian LKS (pair) dalam hal ini siswa tunarunngu setiap kelompok beranggotakan dua orang sehingga dalam satu kelas ada 3 kelompok, peserta didik mendiskusikan hasil pekerjaanya dengan pasangannya (share). Setelah selesai diskusi dengan pasangannya, setiap pasangan berdiskusi dengan pasangan lain dalam satu kelas. Peserta didik membuat kesimpulan dengan bimbingan guru setelah itu peserta didik mengerjakan soal secara individu. Sebagai penutup, guru memberikan tugas untuk dikerjakan di rumah. Guru meminta peserta didik untuk membaca dan menyiapkan materi yang akan didiskusikan pada pertemuan selanjutnya. 
ISSN 2089-8703 (Print) Vol. 6, No. 3 (2017)

ISSN 2442-5419 (Online)

\section{Hasil Pengembangan Instrumen}

Dalam penelitian ini data dikumpulkan secara langsung menggunakan instrumen tes untuk mengetahui kemampuan komunikasi matematis tertulis pada materi pecahan. Sedangkan untuk komunikasi matematis lisan siswa didapat melalui observasi yaitu menggunakan handycame untuk merekam segala aktifitas subjek penelitian, instrumen pedoman wawancara dan proses wawancara dengan guru yang mengajar.

Proses pengumpulan data dilakukan pada tanggal 27 Maret 2017 sampai 13 Juni 2017 saat proses pembelajaran matematika di kelas VII SMPLB N Pringsew. Langkah berikutnya dalam pengumpulan data yaitu menggunakan instrumen bantu kedua berupa wawancara dengan guru yang mengajar matematika. Wawancara ini dilakukan untuk mempertegas dan memverifikasi kebenaran data yang diperoleh dari hasil rekaman handycame.

Hasil analisis data komunikasi matematis tulis pada siswa tunarungu didapat bahwa siswa berkemampuan tinggi (S1) dan sedang (S2) dapat menggunakan simbol atau lambang matematika dengan benar dan dapat menyatakan hasil jawaban secara runtun. Dalam hal ini subyek S1 dan S2 menguasai indikator 1 dan indikator 2 pada kumunikasi matematis tertulis. Subyek yang berkemapuan rendah (S3) hanya menguasi indikator 1 yaitu menggunakan lambang atau simbol matematika secara benar. Adapun indikator 3 yaitu siswa dapat menuliskan gagasan serta dapat menggambarkan situasi masalah dalam bentuk rumus atau model matematika tidak dikuasi oleh subyek berkemampuan tinggi,sedang ataupun rendah. Rangkuman hasil analisis data komunikasi matematis lisan disajikan pada Tabel.1 berikut:

Tabel.1 Komunikasi Matematis tertulis Siswa Tunarunggu

\begin{tabular}{|c|c|c|c|c|}
\hline \multirow{2}{*}{ NO } & \multirow{2}{*}{ Subyek } & \multicolumn{3}{|c|}{ Indikator } \\
\cline { 3 - 5 } & S1 & $\sqrt{ }$ & $\sqrt{ }$ & $\mathbf{3}$ \\
\hline 1. & S2 & $\sqrt{ }$ & $\sqrt{ }$ & - \\
\hline 2. & S3 & $\sqrt{ }$ & - & \\
\hline 3. & & \multicolumn{3}{|c|}{} \\
\hline
\end{tabular}

Hasil analisis data komunikasi matematis lisan diperoleh siswa yang berkemampuan tinggi (S1) dan sedang (S2) mampu mengungkapkan lambang/simbol matematika dengan benar. Kemampuan menggunakan rumus atau model matematika dalam menyampaikan penjelasan hanya dikuasi oleh subyek S2. Sedangkan subyek yang berkemampuan rendah tidak menguasai indikator 1 dan 2. Hasil analisis terangkum pada Tabel 2 berikut:

Tabel. 2. Komunikasi Matematis Lisan Siswa Tunarungu

\begin{tabular}{|c|c|c|c|c|}
\hline \multirow{2}{*}{ NO } & \multirow{2}{*}{ Subyek } & \multicolumn{3}{|c|}{ Indikator } \\
\cline { 3 - 5 } & S1 & $\sqrt{ }$ & - & 2 \\
\hline 1. & S2 & $\sqrt{ }$ & $\sqrt{ }$ & \\
\hline 2. & S3 & - & & \\
3. &
\end{tabular}

Aksioma 
Penelitian ini dilakukan di SMPLB Negeri Pringsewu pada siswa kelas VII Proses pembelajaran menggunakan model pembelajaran Think Pair Share, pada awal kegiatan guru menyampaikan tujuan pembelajaran dan memotivasi siswa. Dalam langkah ini guru menyampaikan tujuan pembelajaran yang akan dicapai melalui model pembelajaran kooperatif tipe TPS. Langkah apersepsi dalam penelitian ini dilakukan melalui tanya jawab. Guru mengecek kemampuan siswa tentang materi sebelumnya dalam hal ini materi tentang bilangan bulat.

Pada kegiatan inti: Guru mempresentasikan secara garis besar tentang materi yang akan didiskusikan, Guru memberikan LKS pada peserta didik tentang materi yang akan didiskusikan dengan memberikan materi yang relevan dan dikerjakan secara individu (think), peserta didik membentuk kelompok sesuai dengan teman duduk dalam satu bangku dengan membawa hasil penyelesaian LKS (pair) dalam hal ini siswa tunarunngu setiap kelompok beranggotakan dua orang sehingga dalam satu kelas ada 3 kelompok, peserta didik mendiskusikan hasil pekerjaanya dengan pasangannya (share). Setelah selesai diskusi dengan pasangannya, setiap pasangan berdiskusi dengan pasangan lain dalam satu kelas. Peserta didik membuat kesimpulan dengan bimbingan guru setelah itu peserta didik mengerjakan soal secara individu. Sebagai penutup, guru memberikan tugas untuk dikerjakan di rumah. Guru meminta peserta didik untuk membaca dan menyiapkan materi yang akan didiskusikan pada pertemuan selanjutnya.

Penelitian ini bertujuan untuk mendeskripsikan komunikasi matematis siswa tunarungu secara lisan dan tertulis setelah pembelajaran matematika dilaksanakan dengan menggunakan model pembelajaran kooperatif tipe TPS. Dari hasil analisis data kemampuan komunikasi matematis lisan dan tertulis didasarkan pada hasil pengamatan yang dilakukan pada saat proses pembelajaran terhadap subjek penelitian. Data didapatkan dari observasi di kelas yang direkam dengan handycame untuk mengumpulkan data interaksi guru dan siswa tunarungu dalam kegiatan pembelajaran matematika.

Pengamatan yang lakukan didasarkan pada indikator komunikasi matematis lisan meliputi: 1) Siswa mampu mengungkapkan lambang atau simbol matematika dengan benar, dimana pada saat proses pembelajaran berlangsung subyek terlihat memperhatikan penjelasan guru mengenai konsep pecahan, saat bekerjasama dalam kelompok berpasangan aktif berdiskusi menentukan jawaban yang tepat yang disepakati bersama. Dari pengamatan kerja kelompok dan presentasi di depan kelas didapatkan bahwa subyek S1 dan S2 dapat menggungkapkan rumus atau simbol matematika dengan benar. Hal ini juga diperkuat dari hasil wawancara dengan guru bahwa beberapa subyek S1, S2 mampu mengungkapkan lambang atau simbol matematika dengan benar walaupun menggunakan isyarat jari dan bahasa lisan yang terbata-taba. Berbeda dengan subyek S3 yang cenderung lebih diam dan harus selalu dibimbing oleh guru dalam menuliskan lambang atau simbol matematika supaya benar.

Indikator yang ke dua pada komunikasi matematis lisan pada siswa tunarunggu dicapai oleh subyek S2 saja. Hal ini dikarenakan subyek S2 lebih jelas intonasi bahasa lisannya daripada subyek S1 dan S3 yang lebih dominan menggunakan isyarat jari sehingga tidak benar saat menggungkapkan lambang/simbol matematika dalam menyampaikan penjelasan. Hal ini juga 
diperkuat dari hasil wawancara dengan guru yang mengatakan bahwa subyek S2 lebih bagus kemampuan komunikasi lisannya diantara temannya satu kelas.

Instrumen tes yang digunakan untuk mendapatkan data komunikasi matematis tertulis siswa menggunakan soal essay yang berjumlah 3 butir soal. Dengan tiap butir soal mengacu pada indikator komunikasi matematis secara tertulis. Soal tes yang diberikan menggunakan materi pecahan biasa dan pecahan campuran. Sebagian besar siswa hanya mampu menuliskan lambang bilangan pecahan yang diperoleh dari gambar namun saat mengerjakan soal terkait konsep operasi penjumlahan, pengurangan, pembagian dan perkalian pecahan siswa tidak mampu menuliskan jawaban secara runtun dan benar terutama pada siswa yang berkemampuan rendah, indikator ini hanya mapu dicapai oleh siswa yang berkemampuan sedang dan tinggi yaitu subyek S1 dan S2.

Hasil tes didapatkan bahwa siswa SLB-B (tunarungu) pada pembelajaran matematika yang menggunakan model pembelajaran kooperatif tipe TPS belum sepenuhnya memenuhi indikator komunikasi matematis lisan dan tertulis. Secara umum anak tunarungu dapat diartikan seseorang yang kehilangan kemampuan mendengar sehingga menghambat proses informasi bahasa melalui pendengarannya, baik memakai maupun tidak memakai alat bantu pendengaran. Kehilangan kemampuan mendengar tersebut diartikan kurang dengar atau tidak dapat mendengar sama sekali. Akibat kurang berfungsinya pendengaran, anak tunarungu mengalihkan pengamatan kepada mata, melalui mata anak tunarungu memahami bahasa lisan atau oral, selain itu melihat ekspresi wajah dan gerakan lawan bicara.
Mata anak tunarungu juga digunakan untuk membaca gerakan bibir orang yang berbicara. Ketiga subyek penelitian ini mengalami gangguan pendengaran dan mengalami kesulitan saat belajar matematika. Namun karena saat proses pembelajaran setiap siswa di pasang-pasangkan dengan rekannya sehingga timbul interaksi dan komunikasi antar siswa tunarungu saat pembelajaran.

Menurut Lyman (1981) TPS merupakan model pembelajaran yang dapat mengaktifkan seluruh siswa selama proses pembelajaran dan memberikan kasempatan untuk bekerja sama antarsiswa yang mempunyai kemampuan heterogen. Lie (2008:57) menyatakan bahwa, Think Pair Share adalah pembelajaran yang memberi siswa kesempatan untuk bekerja sendiri dan bekerjasama dengan orang lain. Ciri utama pada model pembelajaran kooperatif tipe Think Pair Share adalah tiga langkah utamanya yang dilaksanakan dalam proses pembelajaran. Yaitu langkah think (berpikir secara individual), pair (berpasangan dengan teman sebangku), dan share (berbagi jawaban dengan pasangan lain atau seluruh kelas).

Think (berpikir secara individual), pada tahap think, guru mengajukan suatu pertanyaan atau masalah yang dikaitkan dengan pelajaran dan siswa diminta untuk berpikir secara mandiri mengenai pertanyaan atau masalah yang diajukan. Pada tahapan ini, siswa sebaiknya menuliskan jawaban mereka, hal ini karena guru tidak dapat memantau semua jawaban siswa sehingga melalui catatan tersebut guru dapat mengetahui jawaban yang harus diperbaiki atau diluruskan diakhir pembelajaran. Dalam menentukan batasan waktu untuk tahap ini, guru harus mempertimbangkan pengetahuan dasar siswa untuk menjawab pertanyaan yang diberikan, 
jenis dan bentuk pertanyaan yang diberikan, serta jadwal pembelajaran untuk setiap kali pertemuan.

Pair (berpasangan dengan teman sebangku), langkah kedua adalah guru meminta para siswa untuk berpasangan dan mendiskusikan mengenai apa yang telah dipikirkan. Interaksi selama periode ini dapat menghasilkan jawaban bersama. Biasanya guru mengizinkan tidak lebih dari 4 atau 5 menit untuk berpasangan. Setiap pasangan siswa saling berdiskusi mengenai hasil jawaban mereka sebelumnya sehingga hasil akhir yang didapat menjadi lebih baik, karena siswa mendapat tambahan informasi dan pemecahan masalah yang lain.

Share (berbagi jawaban dengan pasangan lain atau seluruh kelas) pada langkah akhir ini guru meminta pasangan-pasangan tersebut untuk berbagi hasil pemikiran mereka dengan pasangan lain atau dengan seluruh kelas. Pada langkah ini akan menjadi efektif jika guru berkeliling kelas dari pasangan satu ke pasangan yang lain, sehingga seperempat atau separuh dari pasanganpasangan tersebut memperoleh kesempatan untuk melapor. Langkah ini merupakan penyempurnaan dari langkah-langkah sebelumnya, dalam arti bahwa langkah ini menolong agar semua kelompok menjadi lebih memahami mengenai pemecahan masalah yang diberikan berdasarkan penjelasan kelompok yang lain. Hal ini juga agar siswa benar-benar mengerti ketika guru memberikan koreksi maupun penguatan di akhir pembelajaran.

Berdasarkan Tabel. 1 dan Tabel 2 disimpulkan bahwa kemampuan komunikasi matematis tertulis subyek S1 dan S2 mampu menguasai indikator 1 dan 2. Sedangkan subyek S3 hanya memenuhi indikator 1. Penguasaan indikator komunikasi matematis lisan siswa tunarungu subyek S1 hanya pada indikator 1, subyek S2 indikator 1 dan 2, sedangkan S3 tidak satupun indikator komunikasi matematis lisan dipenuhi.

Berdasarkan paparan sebelumnya dapat ditarik kesimpulan bahwa kemampuan komunikasi matematis tertulis siswa tunarungu antara lain 1) siswa dapat dapat menggunakan simbol atau lambang matematika secara tepat. Kemampuan ini dikuasi oleh siswa berkemampuan tinggi (S1), sedang (S2), maupun rendah (S3). 2) siswa dapat menyatakan hasil jawaban secara runtun dan benar, kemampuan ini dapat dikuasi oleh Subyek S1 dan S2. Sedangkan indikator ke tiga yaitu: menuliskan gagasan serta dapat menggambarkan situasi masalah dalam bentuk rumus ataupun model matematika tidak satupun subyek yang menguasainya.

Kemampuan komunikasi matematis lisan siswa tunarungu sebagai berikut: 1) siswa dapat menggunakan rumus ataupun model matematika dalam menyampaikan penjelasan, indikator ini dikuasi oleh Subyek S1 dan S2. Indikator yang kedua siswa mampu mengungkapkan lambang atau simbol matematika dengan benar hanya dikuasi oleh subyek S2. Subyek S3 tidak memenuhi satupun indikator komunikasi matematis lisan.

Hal tersebut terjadi dikarenakan anak kesulitan di dalam merangkat kata atau peletakan kata baik dalam pengucapan maupun penulisan. Kemampuan komunikasi yang dimiliki tunarungu terbatas dalam menyampaikan pemikiran, perasaan, gagasan, kebutuhan dan kehendaknya pada orang lain seperti perkataan. Pada remaja tunarungu komunikasi menggunakan isyarat, gerak bibir, ejaan jari, mimic atau gesture, serta pemampaan sisa pendengaran dengan menggunakan alat bantu atau hearing aid.

Daya abstraksi anak tunarungu juga kurang sekali dibandingkan dengan 
mereka yang normal pendengarannya. Obyek dasar matematika yang dipelajari bersifat abstrak, biasa disebut sebagai obyek mental obyek-obyek tersebut merupakan obyek pikiran. "Daya abstraksi yang kurang pada beberapa tugas akibat dari terbatasnya kemampuan berbahasa anak, bukan merupakan suatu keadaan mental retardation atau keterbelakangan mental" (Permanarian, 1996: 13) anak tunarungu kurang dalam kemampuan bahasanya, yang sangatlah berperan dalam kemampuan logika verbal, tetapi tidak berarti tunarungu tidak memiliki kemampuan logika. Sehingga anak tunarungu membutuhkan waktu yang lebih banyak untuk memahami bahasa orang lain dan untuk berbicara. Oleh sebab itu kurang berfungsinya pendengaran, menyebabkan anak tunarungu secara umum memiliki kemampuan komunikasi matematis lisan yang rendah. Upaya meningkatkan pemahaman konsep matematika siswa melalui peningkatan kemampuan komunikasi matematisnya yang dibangun dan dikembangkan dengan menerapkan model pembelajaran TPS kurang maksimal, hal ini karena indikator komunikasi matematis lisan dan tulisan tidak terpenuhi semua oleh siswa.

\section{KESIMPULAN DAN SARAN}

Berdasarkan hasil analisis data dan pembahasan penelitian terhadap siswa yang menjadi obyek penelitian diperoleh kesimpulan sebagai berikut:

Pada komunikasi matematis tertulis subjek yang memiliki kemampuan tinggi (S1), kemampuan sedang (S2) dan kemampuan rendah (S3) dapat menggunakan simbol atau lambang matematika dngan benar. Subyek S1 dan S2 mampu manyatakan hasil jawaban secara runtun dan benar sedangkan subyek S3 tidak dapat menyatakan hasil jawaban secara runtun dan benar. Subyek S1, S2 dan S3 tidak mampu dalam menuliskan gagasan dengan benar serta mengambarkan situasi masalah dalam bentuk model ataupun rumus matematika.

Kemampuan komunikasi matematis lisan pada indikator indikator mengungkapkan lambang atau simbol matematika dengan benar dikuasi oleh subyek S1 dan S2. Sedangkan indikator menggunakan rumus ataupun model matematika untuk menyapaikan penjelasan hanya dikuasi oleh subyek $\mathrm{S} 2$.

Pembelajaran menggunakan Think Pair Share kurang mampu meningkatkan kemampuan komunikasi matematis siswa tunarunggu. Hal ini dapat dilihat dari kemampuan siswa tunarunggu yang berkemampuan rendah (S3) tidak mencapai indikator komunikasi lisan maupun tulisan. Pada penelitian selanjutnya diharapkan untuk bisa menggunakan model pembelajaran yang lebih variatif sehingga mampu meningkatkan komunikasi matematis siswa tunarunggu.

\section{DAFTAR PUSTAKA}

Asmani, J. M. 2011. Tuntunan Lengkap Metodologi Praktis Penelitian Pendidikan. Jogjakarta: Diva Press.

Husna. 2013. Peningkatan Kemampuan Pemecahan Masalah dan Komunikasi Matematis Siswa Sekolah Menengah Pertama melalui Model Pembelajaran Kooperatif Tipe TPS. Jurnal Peluang.Vol 1, No.2, Hal. 81-92

LACOE (Los Angelese County Office of Education). 2004. http://teams.lacoe.edu. 
ISSN 2089-8703 (Print) Vol. 6, No. 3 (2017)

ISSN 2442-5419 (Online)

Lie, A. 2008. Mempraktekkan Cooperative Learning di Ruangruang Kelas. Jakarta: Grasindo.

Munandar. 2014. Penerapan Model Pembelajaran Kooperatif Tipe TPS untuk meningkatkan Kemampuan Komunikasi Matematis Siswa. Jurnal FKIP Unila. Vol 2, No.10, Hal. 1 - 11

Mundia, L. 2010. Problem in Learning Mathematics: Comparison of Brunei Junior High School Students in Classes With and Without Repeaters. Journal of Mathematics Research. Vol. 2 (3), Hal. 150-161
Sugiyono. 2011. Metode Penelitian Kuantitatif Kualitatif dan $R \& D$. Bandung: Alfabeta.

Suningsih, A., Kusmayadi, T. A., dan Riyadi, R. 2014. Eksperimentasi Model Pembelajaran Kooperatif Tipe TTW dan TPS pada Persamaan Garis Lurus Ditinjau dari Karakteristik Cara Berpikir Siswa SMP Negeri Se-Kabupaten Pringsewu.

Sutriningsih, N. 2015. Komunikasi Matematis Siswa Tunaarunggu pada Pembelajaran Matematika di SMPLB Negeri Pringsewu Lampung. Jurnal Litbang Pringsewu. Vol. 1 (1) 